\title{
CLINICAL STUDY OF NECK SWELLINGS
}

\author{
Duddu Gopikrishna ${ }^{1}$, M. Harsha Deepthi², Nishanth Sadhanala ${ }^{3}$
}

${ }_{1}^{1}$ Assistant Professor, Department of General Surgery, Guntur Medical College, Guntur.

2Senior Resident, Department of General Surgery, Guntur Medical College, Guntur.

3Postgraduate Student, Department of General Surgery, Guntur Medical College, Guntur.

\section{BACKGROUND}

ABSTRACT

Neck swelling is a common presentation in the course of number of diseases. This condition is generally not a disease by itself, rather it may be a symptom of many possible underlying problems.

\section{MATERIALS AND METHODS}

The study includes 100 patients with neck swelling attending the Surgical Outpatient Department of Government Hospital, Guntur. Patient's data was recorded. Samples of FNAC were taken from the swelling and sent for cytology. Ultrasonography was performed for the neck swelling and results were interpreted in correlation with cytology.

\section{RESULTS}

Thyroid lesions accounted for the majority (57\%) followed by lymph node enlargement (27\%). Benign lesions were most common, of which thyroid goitres more common in female sex were found. The most common lymph nodal lesion is tuberculous/granulomatous lymphadenitis. In toto malignant lesions accounted for $23 \%$ of cases and their incidence rose sharply after 4th decade. The most common benign lesion was nodular goitre, inflammatory lesion was thyroiditis, most common malignant lesion was metastatic secondaries of neck and papillary carcinoma thyroid which was more common in young females.

\section{CONCLUSION}

The most common single pathological diagnosis in our study was found to be goitrous lesion of thyroid, most likely attributed to the endemicity of fluorosis in the catchment area of the hospital. High index of suspicion of malignancy needs to be borne in mind in dealing with a lymph node swelling in elderly.

\section{KEYWORDS}

Neck Swelling, Thyroid Lesions, FNAC, Ultrasonography.

HOW TO CITE THIS ARTICLE: Gopikrishna D, Deepthi MH, Sadhanala N. Clinical study of neck swellings. J. Evolution Med. Dent. Sci. 2017;6(94):6841-6844, DOI: 10.14260/jemds/2017/1482

\section{BACKGROUND}

Neck swellings are frequently encountered in the clinical practice and the cause is usually benign. In general practice inflammatory lymph nodes are the most common cause,(1) mostly with tuberculous aetiology in Indian environment due to malnourishment and poor socioeconomic status. However, the lump may be the presentation of more serious disease (ex-malignancy or chronic infection) and so a thorough assessment and diagnosis are essential. If there is any doubt as to the cause, then the patient should be reviewed and/ or referred for specialist assessment. Patients over the age of 40 are more likely to have a neoplastic cause. Inflammatory, congenital and traumatic causes are more common in younger patients, but neoplasm should still be borne in mind.(2)

Fine needle aspiration cytology (FNAC) is a simple, quick and cost effective method to sample superficial masses found in the head and neck. ${ }^{(3)}$

'Financial or Other Competing Interest': None.

Submission 23-11-2017, Peer Review 03-12-2017,

Acceptance 07-12-2017, Published 18-12-2017.

Corresponding Author:

Dr. Duddu Gopikrishna,

D 308, NCC Urban Park Square,

Uma Maheswara Colony,

Pattabhipuram, Guntur-522006,

Andhra Pradesh, India.

E-mail: gopisteve@yahoo.com

DOI: $10.14260 /$ jemds $/ 2017 / 1482$

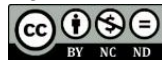

The technique is performed in the outpatient department and causes minimal trauma to the patient. An early differentiation of benign from malignant pathology is beneficial, as it greatly influences the planned treatment.(4) It can be both diagnostic and therapeutic in cystic swellings.(5) It is helpful for the diagnosis of salivary gland tumours where it can differentiate between a malignant and a benign tumour with over $90 \%$ accuracy.(6)

Two new dimensions of medical practice per our environment are non-invasive diagnosis and cost control. UItrasonography qualifies eminently in regards. While there have been many reports on its use in thyroid diseases, there are few reports on its general use in the diagnosis of head and neck diseases. Ultrasonography gives accurate information as to the form and content of cervical masses. It enables us to distinguish solid from cystic lesions. It may alert us to the probabilities of malignant versus benign nature of neck swellings.

This study is an effort to assess the incidence of various swellings in neck through clinical examination and usefulness of FNAC as well as ultrasonography.

\section{MATERIALS AND METHODS \\ Design}

A hospital-based descriptive study.

\section{Setting}

Patients coming to outpatient department of general surgery of Govt. General Hospital, Guntur. 


\section{Duration}

December 2014 to October 2016.

\section{Sample Size}

100 Cases of patients in outpatient Department of General Surgery, GGH, Guntur with neck swellings were studied.

\section{Methodology/ Inclusion Criteria}

Patients of age > 15 yrs. presenting with asymptomatic/symptomatic neck swellings to the outpatient department of Government General Hospital, Guntur.

\section{Exclusion Criteria}

Patients unwilling for inclusion into study.

\section{Method of Collection of Data}

Data was collected using a detailed well-designed proforma. Informed written consent was taken from all patients. According to proforma detailed history was taken, thorough examination was carried out and basic relevant investigations were done in all the patients to arrive at a provisional diagnosis.

All the cases of neck swellings were sent to Department of Pathology, GGH, Guntur where fine needle aspiration biopsy was done 21 - 23 gauge needle attached to the $10 \mathrm{~mL}$ plastic disposable syringe.

The patient was also investigated by ultrasonography of neck to determine the position of the swelling and its relation to vital structures and other important features of the swelling.

Statistical Analysis: Data was entered using Microsoft Excel 2010 version and analysis using Epi Info version 7. Numerical data was presented in mean and standard deviation and categorical variables in percentages and proportions.

\section{RESULTS}

Out of the total 100 patients, there were 39 males and 61 females showing a female preponderance (1.56: 1). Age ranged from 15 - 84 years, the mean age being 41.85 years.

\section{Tissue of Origin of Lesion}

Of the 100 neck swellings when categorised based on tissue of origin, there is clear preponderance of thyroid swellings accounting to $57 \%$ followed by swellings of lymph nodes $27 \%$, then $15 \%$ contributed by soft tissue swellings (lipoma, abscess, soft tissue tumours). Lastly, with $1 \%$ incidence is salivary gland swelling.

\section{Type of Lesion}

Based on type of lesions the data regarding neck swellings was analysed and it was deducted that most of the neck swellings were benign (43\%) followed by inflammatory (34\%) swellings. Malignant swellings occupied the 3rd place amongst the neck swellings.

\begin{tabular}{|c|c|c|}
\hline Type of Lesion & Number & Percentage \\
\hline Inflammatory & 34 & $34 \%$ \\
\hline Benign & 43 & $43 \%$ \\
\hline Malignant & 23 & $23 \%$ \\
\hline Total & 100 & $100 \%$ \\
\hline \multicolumn{2}{|c|}{ Table 1. Based on Type of Lesion }
\end{tabular}

\section{Pathological Diagnosis}

The most common single pathological diagnosis was Goitrous lesion of thyroid accounting 38\% of cases followed by Tuberculous lymphadenitis (11\%). Most common malignant lesion was metastatic secondaries of neck and papillary carcinoma thyroid, which was more common in young females. In toto malignant lesions accounted for $23 \%$ of cases and their incidence rose sharply after 4 th decade. In segment of people with HIV positive status, which occupied $10 \%$ of the sample. TB lymphadenitis was more common (70\%).

Analysis has revealed that tubercular aetiology of lymph nodes looked to be more common in males (10: 1). Goitrous lesions of thyroid showed a female preponderance (8.5: 1). Malignant lesions of thyroid, especially papillary carcinoma appeared to be more common in females.

\begin{tabular}{|c|c|c|}
\hline $\begin{array}{c}\text { Tissue of } \\
\text { Origin }\end{array}$ & Pathology & Total \\
\hline \multirow{4}{*}{$\begin{array}{c}\text { Lymph } \\
\text { Nodes }\end{array}$} & TB/ Granulomatous LN & 11 \\
\cline { 2 - 3 } & Reactive lymphadenitis & 4 \\
\cline { 2 - 3 } & Non-Hodgkin's lymphoma & 6 \\
\cline { 2 - 3 } & Hodgkin's lymphoma & 1 \\
\cline { 2 - 3 } & Metastatic deposit to LN & 6 \\
\hline \multirow{3}{*}{$\begin{array}{c}\text { Thyroid } \\
\text { Lesions }\end{array}$} & Cystic & 2 \\
\cline { 2 - 3 } & Goitre & 38 \\
\cline { 2 - 3 } & Thyroiditis & 9 \\
\hline \multirow{2}{*}{$\begin{array}{c}\text { Soft } \\
\text { Tissue }\end{array}$} & Malignant & 6 \\
\cline { 2 - 3 } & Lipoma & 1 \\
\hline Salivary & Abscess & 1 \\
\hline Gland & $\begin{array}{c}\text { Mucoepidermoid carcinoma } \\
\text { Submandibular gland }\end{array}$ \\
\hline \multicolumn{2}{|c|}{ Total } & $\mathbf{1 0 0}$ \\
\hline \multicolumn{2}{|c|}{ Table 2. Incidence based on Pathology } \\
\hline \multicolumn{2}{|c|}{}
\end{tabular}

\section{DISCUSSION}

Most of the catchment of the Government General Hospital is from the rural areas. The people from these rural areas have low socioeconomic status and mostly uneducated. Most of the males regularly chew tobacco and smoke. Mostly females are housebound and ignorant about their health and nutrition. So, infectious and malignant conditions constitute a significant proportion of health problems among them.

The present study was conducted in the Department of General Surgery, GGH, Guntur from December 2014 to October 2016. There were 61 female patients and 39 male patients with $\mathrm{M}$ : $\mathrm{F}$ ratio of $1: 1.56$. There was clear female preponderance. Although, there were many clinical studies that reported uneven data regarding gender distribution, this study was comparable to the study of Modi et al,(7) Soni et $\mathrm{al}^{(8)}$ and Ahmad et al(9) whose studies showed female preponderance. The youngest patient was $15 \mathrm{yrs}$. old and oldest was 84 yrs., mean age being 41.5 yrs. Age distribution of the swellings when assessed showed clustering of the lesions from the age group of 20 yrs. to 40 yrs. in the active period of one's lifetime. This could be because of the physiological demand that could not meet the daily demands of the patients who are mostly undernourished manual labourers below poverty line. This study has results comparable to the study done by Hitenderbasista et al(10) and Manjula et al.(11) The inflammatory and benign lesions were found to be most common below the age of 40 yrs. The 
prevalence of malignant lesions rose sharply after 4th decade, which is expected as the same happens in rest of the body.(12)

Total of 100 neck swellings were evaluated, out of which 57 swellings were of thyroid origin, 27 were of lymph nodal origin, 15 were of soft tissue origin and 1 was of salivary gland origin. Present study showed clear preponderance of thyroid swellings over lymph nodal swellings. Though many other studies had lymph nodal swellings in greater proportion,(9)(11)(13) present study showed thyroid swellings in dominant proportion, that too in female sex. This study was comparable to study done by Hitenderbasista et al,(10) where thyroid was the most common tissue of origin of lesion.

The most common single pathological diagnosis was Goitrous lesion of thyroid (38\%) followed by Tuberculous affection of lymph node (11\%). Our results were comparable to the study by HitenderBasista et al.(10) Many of the other studies in the literature showed predominance of tubercular lymphadenitis as in studies by Ahmad et al,(9) Garima Gupta et al(13) and reactive lymphadenitis in study by Manjula et al.(11) However, the incidence of Tubercular lymphadenitis in our study $11 \%$ is still comparable to studies of Manjula et al(11) $16.84 \%$ and Jindal et al(14) $19.84 \%$.

Our Government General Hospital caters most of the patients from fluorosis endemic areas. This might be the reason for higher prevalence of iodine deficiency disorders, such as thyroid goitre. The fluoride endemicity coupled with higher malnutrition and ignorance about health in females might prove as the reason for female gender preponderance of neck swellings.

The inflammatory lesions contributed to $34 \%$ of cases in the present study. This is in contrast to $74.66 \%$ in study by Garima Gupta et al,(13) the reason being the predominance of benign thyroid lesions in the present study. Tubercular affection of lymph node and abscess, i.e. the infective ones (53\%) occupied the majority of inflammatory lesions, malnutrition and health ignorance the most plausible reasons.

In present study, malignant lesions comprised $22 \%$ of the neck masses. Frequency of incidence in different studies

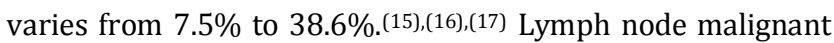
lesions comprised of Metastatic deposits, Hodgkin's and NonHodgkin's lymphoma. Metastatic deposits to the lymph nodes were mostly from squamous cell carcinoma elsewhere. Thyroid malignancies were mostly papillary carcinomas $(80 \%)$, which were found to be more common in females $<40$ years. Among the salivary gland lesions, one case of mucoepidermoid carcinoma was reported. Our results of thyroid and salivary gland malignancies were found similar to the study of Jindal et al.(14)

Lipoma was found to be the most common benign soft tissue lesion of neck (6\%). It could be considered similar to the studies of Manjula et al and Jindal et al.(11),(14)

\section{CONCLUSION}

The most common single pathological diagnosis in our study was found to be Goitrous lesion of thyroid, most likely attributed to the endemicity of fluorosis in the catchment area of the hospital. High index of suspicion of malignancy needs to be borne in mind in dealing with a lymph node swelling in elderly.

Fine needle aspiration cytology clubbed with ultrasonography offers simple methods of diagnosis of neoplastic and non-neoplastic lesions in the neck to confirm clinical diagnosis. It can be performed as an outpatient procedure without complications. The procedure is acceptable to most of the patients. There is no need for anaesthesia and speedy results are available.

\section{REFERENCES}

[1] Roland N, Bradley PJ. Neck swellings. BMJ 2014;348:g1078.

[2] Rosenberg TL, Brown JJ, Jefferson GD, et al. Evaluating the adult patient with a neck mass. Med Clin North Am 2010;94(5):1017-29.

[3] Orell SR, Sterrett GF, Walters NI, et al. Manual and Atlas of FNAC. 2nd edn. New York: Churchill Livingstone 1995: p. 250.

[4] Watkinson JC, Wilson JA, Gaze M, et al. Chapter-2 and 20-21. Stell and Maran's Head and neck surgery. $4^{\text {th }}$ edn. Oxford: Butterworth-Heinemann 2000.

[5] Afridi S, Malik K, Wahed I. Role of fine needle aspiration biopsy and cytology in breast lumps. J College of Physicians and Surgeons Pakistan 1995;5:75-7.

[6] Burnand KG, Young AE, Lucas J, et al. The new Aird's companion in surgical studies. $3^{\text {rd }}$ edn. China: Elsevier 2005.

[7] Modi P, Oza H, Bhalodia J. Utility and adequacy of fine needle aspiration cytology in head and neck lesions: a hospital based study. Int J Sci Stud 2014;2:100-5.

[8] Soni S, Pippal SK, Yashveer B, et al. Efficacy of fine needle aspiration cytology in diagnosis of neck masses. Vol 3-1. World Articles in Ear, Nose and Throat 2010. www.waent.org.

[9] Ahmad T, Naeem M, Ahmad S, et al. Fine Needle Aspiration Cytology (FNAC) and neck swellings in the surgical outpatient. J Ayub Med Coll Abbottabad 2008;20(3):30-2.

[10] Basista H, Modwal A, Prasad B. Clinicopathological evaluation of neck masses. Sch J App Med Sci 2015;3(9B):3235-41.

[11] Manjula K, Prasad CSBR, Gayathri BN, et al. Cytomorphological study of lateral neck swellings. Journal of Clinical And Diagnostic Research 2011;5(5):1016-9.

[12] Hetzel BS, Potter BJ, Dulberg EM. The iodine deficiency disorders: nature, pathogenesis and epidemiology. World Rev Nutr Diet 1990;62:59-119.

[13] Gupta G, Joshi DS, Shah A, et al. FNAC of head and neck swellings. GCSMC J Med Sci 2014;3(1):38-41.

[14] Jindal U, Singh K, Baghla A, et al. Spectrum of head and neck swellings in the rural population of India based on fine needle aspiration findings. The Internet Journal of Head and Neck Surgery 2012;5(2):1-6.

[15] El Hag IA, Chiedozi LC, al Reyees FA, et al. Fine needle aspiration cytology of head and neck masses. Seven years' experience in a secondary care hospital. Acta Cytol 2003;47(3):387-92. 


\section{Jemds.com}

[16] Sheahan P, Fitzgibbon JG, Leary OG, et al. Efficacy and pitfalls of fine needle aspiration in the diagnosis of neck masses. Surg J R Coll Surg Edinb Irel 2004:152-7.
Original Research Article

[17] Kamal F, Niazi S, Nagi AH, et al. Fine needle aspiration cytology (FNAC): an experience at King Edward Medical College, Lahore. Pak J Pathol 1996;7:33-6. 